\title{
Memahami Psikologi Remaja
}

\author{
RIRYN FATMAWATY
}

Universitas Islam Lamongan

fatmawatyriryn@gmail.com

\begin{abstract}
:
Dunia remaja adalah dunia yang penuh warna dan unik. Dari sekian untaian pertumbuhan dan perkembangan remaja, masa yang paling sering menjadi perhatian tentu saja adalah ketika masa pubertas itu datang.. Jenjang pertumbuhan secara jasmani tersebut dapat dipakai sebagai ciri pertumbuhan remaja di tingkat awal yang selanjutnya akan dilanjutkan dengan masa ketika remaja mengalami fase penyesuaian diri antar-pribadi dan lingkungan sosial yang lebih luas. Sejak itulah muncul berbagai kelompok remaja yang disebut dalam berbagai istilah. Di dalam artikel ini, terdapat uraian seputar perkembangan psikologi remaja, mulai dari masa perkembangan sampai dengan aspek-aspek perkembangan remaja yang memaparkan tentang perubahan fisik, kognisi dan social serta harapan-harapan terhadap remaja. Kesimpulannya anak dan remaja adalah generasi penerus, mereka menjadi bakal atau calon yang penting. yang akan menggantikan tugas-tugas para seniornya, yakni meneruskan membangun bangsa dan negara. Tanpa mereka maka negara bukan apa-apa, maka seyogyanya kita bisa memahami pesikologi, sikap dan kemauan-kemauan mereka sehingga akan tercipta hubungan yang harmonis yang bisa menjadikan remaja menjadi generasi yang aktif dan produktif.
\end{abstract}

Kata kunci: psikologi, remaja

\section{Pendahuluan}

Dalam perkembangan kepribadian seseorang, masa remaja memiliki arti yang khusus, namun begitu masa remaja mempunyai tempat yang tidak jelas dalam rangkaian proses perkembangan seseorang. Hal itu dikarenakan remaja tidak termasuk golongan anak, tetapi ia tidak pula termasuk golongan orang dewasa. Seorang anak masih belum selesai perkembangannya, orang dewasa dapat dianggap sudah berkembang penuh. Sedangkan Remaja walaupun sudah mulai berkembang namun belum mampu untuk menguasai fungsi fisik psikisnya dengan baik. 
Remaja berada dalam status interim sebagai akibat daripada posisi yang diberikan oleh orang tua dan sebagian diperoleh dari usaha mereka sendiri yang selanjutnya memberikan prestise tertentu padanya. Status ini berhubungan dengan masa peralihan yang timbul sesudah pemasakan seksual (pubertas). Masa peralihan ersebut diperlukan untuk mempelajari remaja mampu memikul tanggung jawabnya nanti dalam masa dewasa. Oleh sebab itu suatu pendidikan yang emansipatoris akan membantu remaja untuk melepaskan status interimnya supaya ia dapat menjadi dewasa yang bertanggung jawab.

\section{Fase-fase Masa Remaja}

Suatu analisa yang cermat mengenai semua aspek perkembangan dalam remaja, secara global masa remaja berlangsung antara umur 12-21 tahun, dengan pembagian 12-15 tahun :masa remaja awal, 15-18 tahun masa remaja pertengahan, 18-21 tahun : masa remaja akhir.

Dalam buku-buku Jerman masih ada pembagian yang lain lagi yaitu pembagian dalam prapubertas (masa peralihan dari masa anak-anak ke masa remaja), pubertas (masa pemasakan seksual), dan adolesensi (masa remaja akhir sebelum memasuki masa dewasa).

Pra pubertas adalah periode sekitar 2 tahun sebelum terjadinya pemasakan seksual yang sesungguhnya tetapi sudah terjadi perkembangan fisiologis yang berhubungan dengan pemasakan beberapa kelenjar endoktrin. Kelenjar endoktrin adalah kelenjar yang bermuara secara langsung di dalam saluran darah. Zat-zat yang dikeluarkan disebut hormon. Hormonhormon tadi memberikan stimulasi pada badan anak sedemikian rupa, hingga anak merasakan rangsangrangsang tertentu, suatu rangsang hormonal yang menyebabkan suatu rasa tidak tenang dalam diri anak suatu rasa yang belum pernah dialami sebelumnya, yang tidak dimengertinya dan yang mengakhiri tahun-tahun anak yang menyenangkan.

Masa pubertas atau masa pemasakan seksual umumnya terjadi ntara usia 12-16 tahun pada remaja laki-laki dan 11-15 tahun pada remaja wanita. Pubertas awal pada remaja wanita ditandai dengan menstruasi, sedangkan remaja laki-laki ditandai dengan masa mimpi pertama yang tanpa disadarinya mengeluarkan sperma. Biasanya perkembangan biologis gadis lebih cepat satu tahun dibandingkan perkembangan biologis seorang pemuda.

Masa adolesen sebagai masa remaja akhir atau batas dewasa awal umumnya antara usia 18-21 tahun. Walaupun masih banyak ditemukan seorang anak yang berusia lebih dari 21 tahun tetapi masih dalam pengawasan orang tuanya dan belum bisa hidup mandiri secara ekonomi. Dalam kasus di atas paling tidak remaja yang sudah diambang masa dewasa sudah mengerti norma-norma masyarakat tanpa harus didikte, sudah memikirkan rencana kehidupan 
selanjutnya dan sudah berfikir secara bijaksana.

\section{Ciri-Ciri Masa Remaja}

Seperti halnya dengan semua periode yang peting selama rentang kehidupan, masa remaja mempunyai ciri-ciri tertentu yang membedakan dengan periode sebelum dan sesudahnya. Ciri-ciri tersebut adalah :

\section{Masa Remaja sebagai Periode yang Penting}

Ada beberapa periode yang lebih penting daripada beberapa periode lainnya, karena akibatnya yang langsung terhadap sikap dan perilaku, dan ada lagi yang penting karena akibat-akibat jangka panjangnya. Pada periode remaja, baik akibat langsung maupun akibat jangka panjang tetap penting. Ada periode yang penting karena akibat fisik dan ada lagi karena akibat psikologis. Pada periode remaja kedua-duanya sama-sama penting.

\section{Masa Remaja sebagai Periode Peralihan}

Peralihan dari satu tahap perkembangan ke tahap berikutnya bukan berarti terputus dengan periode sebelumnya, tetapi apa yang telah terjadi sebelumya akan meninggalkan bekasnya pada apa yang terjadi sekarang dan yang akan datang.

Masa remaja sebagai periode peralihaan memiliki status yang tidak jelas dan terdapat keraguan akan peran yang dilakukan. Pada masa ini, remaja bukan lagi seorang anak dan juga bukan pula orang dewasa. Status remaja yang tidak jelas ini memberi waktu kepadanya untuk mencoba gaya hidup yang berbeda dan menentukan pola perilaku, nilai dan sifat yang paling sesuai bagi dirinya.

\section{Masa Remaja sebagai Periode Perubahan}

Ada lima perubahan yang sama dan hampir bersifat universal pada setiap remaja. Pertama, meningginya emosi yang intensitasnya bergantung pada tingkat perubahan fisik dan psikis yang terjadi. Kedua perubahan tubuh - yang akan lebih dijelaskan pada aspek perkembangan. Ketiga perubahan minat dan peran yang diharapkan oleh kelompok sosial untuk diperankan. Keempat dengan berubahnya minat dan pola perilaku, mka nilai-nilai juga berubah. Apa yang pada masa kanak-kanak dianggap penting, sekarang sudah tidak penting lagi, contohnya dalam memiliki teman sudah tidak penting lagi aspek kuantitas tapi lebih pada aspek kualitas.

\section{Masa Remaja sebagai Usia Bermasalah}

Masalah masa remaja sering menjadi nasalah yang sulit diatasi baik oleh anak laki-laki maupun anak perempuan Terdapat dua alasan bagi kesulitan itu. Pertama, sepanjang masa kanak-kanak, sebagain masalah seringkali diselesaikan oleh orang tua dan guru-guru sehingga kebanyakan remaja tidak berpengalaman dalam mengatasi masalah. Kedua, para remaja merasa diri mandiri, menolak bantuan orang tua dan guru-guru. 
tetapi minimnya pengalaman menjadikan penyelesaian seringkali tidak sesuai harapan.

\section{Masa Remaja sebagai Masa Mencari Identitas}

Pada tahun-tahun awal masa remaja, penyesuaian diri dengan kelompok masih penting bagi laki-laki maupun perempuan. Lambat laun mereka mulai mendambakan identitas diri dan tidak puas lagi dengan menjadi sama dengan teman-teman dlam segala hal, seperti sebelumnya.

Identitas diri yang dicari remaja berupa usaha untuk menjelaskan siapa dirinya, apa peranannya dalam masyarakat, apakah ia seorang anak ataukah orang dewasa, apakah nantinya ia dapat menjadi seorang ayah atau ibu, apakah ia mampu percaya diri dan secara keseluruhan apakah ia akan berhasil ataukah gagal?.

\section{Masa Remaja sebagai Usia yang Menimbulkan Ketakutan}

Anggapan stereotip budaya bahwa remaja adalah anak-anak yang tidak rapi, yang tidak dapat dipercaya dan cenderung merusak, menyebabkan orang dewasa yang harus membimbing dan mengawasi kehidupan remaja muda takut bertanggung jawab dan bersikap tidak simpatik terhadap perilaku remaja yang normal.

\section{Masa Remaja sebagai Masa yang Tidak Realistis}

Remaja cenderung memandang kehidupan melalui kaca berwarna merah jambu. Ia melihat dirinya sendiri dan orang lain sebagaimana yang ia inginkan dan bukan sebagaimana adanya, terlebih dalam hal cita-cita. Cita-cita yang tidak realistik ini, tidak hanya bagi dirinya sendiri tetapi juga bagi keluarga dan teman-temannya. Hal ini menyebabkan meningginya emosi yang merupakan ciri dari awal masa remaja.semakin tidak realistic citacitanya semakin ia menjadi marah. Remaja akan sakit hari dan kecewa apabila orang lain mengecewakannya atau kalau ia tidak berhasil menacpai tujuan yang ditetapkannya sendiri.

\section{Masa Remaja sebagai Ambang Masa Dewasa}

Dengan semakin mendekatnya usia kematangan yang sah, para remaja menjadi gelisah untuk meninggalkan stereotip belasan tahun dan untuk memberikan kesan bahwa mereka sudah hampir dewasa. Berpakaian dan bertindak seperti orang dewasa ternyata belumlah cukup. Oleh karena itu, remaja mulai memusatkan diri pada perilaku yang dihubungkan dengan status dewasa, yaitu merokok, minum minuman keras, menggunakan narkoba, dan terlibat dalam perbuatan seks. Di sinilah diperlukan peran orang tua dalam mendidik remaja agar tidak salah dalam mengaktualisasikan kedewasaannya.
Aspek-Aspek
Perkembangan Remaja 
Pada masa perkembangan remaja ini ada beberapa aspek yang sangat menonjol perkembangannya. Antara lain adalah sebagai berikut :

\section{Perkembangan Fisik}

Secara umum, pertumbuhan dan perkembangan fisik sangat pesat pada usia 12/13-17/18 tahun. Pada masa ini, remaja merasakan ketidaknyamanan dan ketidakharmonisan pada diri mereka karena anggota badan dan otot-otonya tumbuh secara tidak seimbang.

Pertumbuhan otak secara cepat terjadi pada usia 10-12/13 dan 1416/17 tahun. Pertumbuhan otak wanita meningkat 1 tahun lebih cepat daripada laki-laki yaitu pada usia 11 tahun, sedangkan pertumbuhan otak laki-laki meningkat $2 x$ lebih cepat dari pada wanita dalam usia 15 tahun.

\section{Perubahan Eksternal}

Untuk tinggi rata-rata anak perempuan mencapai tinggi yang matang pada usia anatar 17-18 tahun. Sedangkan laki-laki 1 tahun lebih lambat dari pada perempuan. Untuk berat perubahan berat badan mengikuti jadwal yang sama dengan perubahan tinggi, tetapi berat badan sekarang tersebar ke bagian-bagian tubuh yang tadinya hanya mengandung sedikit lemak atau tidak mengandung lemak sama sekali. Sedang untuk organ seks, organ seks laki-laki maupun perempuan akan mencapai ukuran yang matang pada akhir masa remaja. Pada seks, anak perempuan memulai pestanya lebih cepat daripada anak laki-laki. Untuk proporsi tubuh : berbagai bagian tubuh lambat laun akan menunjukkan perbandingan yang baik, misalnya badan melebar dan memanjang yang mengakibatkan tubuh tak kelihatan terlalu panjang.

\section{Perubahan Internal}

a) Sistem Pencernaan

1. Perut menjadi lebih panjang sehingga tidak terlalu menyerupai bentuk pipa.

2. Hati bertambah berat dan kerongkongan bertambah panjang.

3. Otot-otot di perut dan dindingdinding usus menjadi lebih tebal dan kuat.

4. Usus bertambah panjang dan bertambah besar.

b) Sistem Peredaran Darah : Jantung tumbuh pesat pada masa remaja pada usia 17/18 tahun, beratnya 12 kali berat pad awaktu lahir. Panjang dan tebal dinding pembuluh darah meningkat dan mencapai tingkat kematangan bilamana jantung sudah matang.

c) Jaringan Tubuh : perkembangan kerangka berhenti rata-rata pada usia 18 tahun, sedangkan jaringan selain tulang terus berkembang sampai tulang mencapai ukuran matang.

d) Sistem Pernafasan : kapasitas paru-paru anak perempuan hamper matang pad ausia 17 taahun, anak laki-laki mencapai tingkat kematangan beberapa tahun kemudian. 
Perkembangan emosi pada masa remaja ini cenderung lebih tinggi dari masa anak-anak. Hal ini dikarenakan mereka berada di bawah tekanan social dan menghadapi kondisi yang baru. Sedangkan selama mereka pada masa kanak-kanak kurang mempersiapkan diri untuk menghadapi kehidupan bermasyarakat. Meskipun ketika pada masa remaja emosianya sama dengan masa kanak-kanak Cuma berbeda pada rangsangan yang membangkitkan emosi dan derajat

Abu ahmadi dan Munawar Sholeh (1991:212) berpendapat bahwa kematangan emosi anak laki-laki dan perempuan pada akhir remajanya akan terlihat ketika ia dapat menahan emosinya di hadapan orang lain melainkan menunggu saat dan tempat yang paling tepat untuk meluapkan amarahnya dengan cara-cara yang lebih dapat diterima. Kematangan emosi juga ditampakkan dengan menilai masalah secara kritis terlebih dahulu daripada yang emosional, bukan sebaliknya. Dengan demikian remaja dapat mengabaikan banyak rangsangan yang dapat menimbulkan ledakan emosi, sehingga dapat menstabilkan emosi.

\section{Perkembangan Kognisi}

Mulai dari usia 12 tahun, proses pertumbuhan otak telah mencapai kesempurnaan. Pada masa ini, sistem syaraf yang memproses informasi berkembang secara cepat dan telah terjadi reorganisasi lingkaran syaraf lobe frontal yang berfungsi sebagai kegiatan kognitif tingkat tinggi, yaitu kemampuan meruimuskan perencanaan strategis atau mengambil keputusan. Lobe frontal ini terus berkembang sampai usia 20 tahun atau lebih. Perkembangan lobe frontal ini sangat berpengaruh pada kemampuan intelektual remaja.

\section{Perkembangan Sosial}

Social cognition berkembang pada masa remaja. Social Cognition yaitu kemampuan untuk memahami orang lain. Remaja dapat memhami orang lain sebagai individu yang unik, baik menyangkut sifat-sifat pribadi, minat nilai-nilai maupun perasaanya. Pemahaman ini mendorong remaja untuk menjalin hubungan sosial yang lebih akrab dengan mereka, terutama teman sebaya.

\section{Sifat Dan Sikap Remaja}

Abu ahmadi dan Munawar Sholeh (1991:87) menambahkan bahwa, pada masa prapubertas selain ditandai oleh kematangan jasmani secara primer dan sekunder juga ditandai dengan kematangan tertier diantaranya timbulnya perasaanperasaan negative, ingin lepas dari kekuasaan orang tua, menentang lingkungan, gelisah dan pesimistis. Hal ini dimaksudkan anak sebagai bentuk aktualnya dalam menyamakan statusnya dengan orang dewasa.

Sedang pada masa pubertas anak mulai aktif mencari keakuannyapedoman hidup dengan penuh semangant tetapi kadang masih belum memahami hakekat dari sesuatu yang dicarinya (masa strumund drang). Abu 
ahmadi dan Munawar Sholeh (1991:88) mengatakan bahwa, pada masa ini ditemui tiga tanda diantaranya sebagai berikut :

1. Dalam penemuan akunya biasanya anak cenderung bersikap introvert atau tetutup, penuh keanggungan dan senang termenung

2. Dalam kegiatan mencari pedoman hidup cenderung bersikap menerima norma-norma susila dan agama, serta timbul perasaan "Merindu Puja"

3. Pada kegiatan memasukkan diri pada masyarakat bersikap mulai mengenal macam corak kehidupan meski belum sempurna membedakan dan menyeleksinya.

Pada masa Adolesen seseorang sudah dapat mengetahui kondisi dirinya dan tenang kejiwaannya serta mempunyai sifat tenang dan seimbang kejiwaannya, menerima system tata nilai secara positif dan mulai bertangung jawab, marah dan konstraktif terhadap masyarakat. Sifat dan sikap remaja adolesen:

a) Menemukan pribadinya, menentukan cita-citanya, menggariskan jalan hidupnya bertanggung jawab, memnghimpun normanorma sendiri

b) Mulai tampak garis-garis perkembangan yang diikutinya di kemudian hari

c) Erotik da seksualitas yang pada masa pubernya dulu terpisah, kini dilebur menjadi satu d) Mulai menyadari bahwa mengecam itu memang mudah, tetapi ternyata melaksanakan itu sukar. (Zulkifli,1995:72)

\section{Peran Remaja \& Lingkungannya}

Yusuf Syamsu, dalam (Psikologi Pekembangan Anak dan Remaja, 2002:06) mengklasifikasikan sebagai berikut:

1. Di lingkungan keluarga

- Menjalin hubungan yang baik dengan para anggota (orang tua dan keluarga)

- Menerima otoritas orang tua (mengetahui peraturan yang ditetapkan orang tua)

- Menerima tanggung jawab dan batasan-batasan (norma) keluarga

- Berusaha untuk membantu anggota keluarga sbagi individu maupun kelompok dalam mencapai tujuannya.

2. Di lingkungan Sekolah

- Bersikap respek dan mau menerima peraturan sekolah

- Berpartisipasi dalam kegiatankegiatan sekolah

- Menjalin persahabatabndenga teman-teman di selolah

- Bersikap hormat terhadap guru, pemimpin sekolah dan staf lainnya

- Membantu sekolah dalam merealisasikan tujuan-tujuannya

Pada umumnya masa remaja adalah masa belajar di sekolah menengah pertama atau setingkat (A. M. P Knoers Dkk,1982:301). Yusuf Syamsu (2002:06) menambahkan 
bahwa, remaja adalah calon-calon pemimpin bangsa yang harus menjalin masa pendidikan di sekolah, tetapi kalau kita jumpai di pelosok-pelosok desa banyak remaja yang sudah putus sekolah dengan alasan-alasan sebagai berikut :

- Alasan ekonomi: anak-anak diharapkan dapat membantu mencari nafkah orang tuanya atau orang tua tidak sanggup membiayai ongkos pendidikan anak-anaknya

- Alasan Psikologis: para remaja ingin mewujudkan dirinay sendiri, mereka ingin mencari nafkah sendiri, ingin merdeka dan menentukan kehidupannya sendiri

- Alasan Sosiologis: berhubungan dengan watak sosial, dan watak ini menyebabkan tingkah laku seseorang sangant terikat dengan lingkungan

3. Di lingkungan Masyarakat

- Mengakui dan respek terhadap terhadap hak-hak orang lain

- Memelihara jalinan persahabatan dengan orang lain

- Bersikap simpati altruis terhadap kesejahteraan orang lain.

\section{Peranan Orang Tua Terhadap Remaja}

Orang tua adalah orang yang paling dekat hubungan kekerabatan dengan remaja. Tetapi banyak ditemukan fakta dilapangan bahwa antara orang tua dan remaja sering kali berbeda pandanagan, seringkali mereka lebih memenitingkan teman bermain daripada kepentingan ornag atua atau keluarganya. Hal ini dikarenakan kurangnya komunikasi dari hati ke hatiantara remaja dengan orang tuanya.

Abu ahmadi dan Munawar Sholeh (1991:98-990) mengatakan bahwa, sebagai orang tua hendaknya kita berusaha, agar apa yang merupakan kewajiban anak-anak dan tuntutan kita sebagai orang tua mereka kenal dan laksanakan, sesuai dengan kemampuan mereka dan kemampuan kita sebagai orang tua. Jika hal ini dapat kita kerjakan, maka konflik dan frustasi pada kedua belah pihak dapat dihindarkan atau paling sedikit diselesaikan.

Peranan orang tua dapat diterapkan pada hal-hal berikut ini:

\section{a. Children learn what they live}

Hendaknya orang tua berusaha menjadi contoh kepribadian yang hidup atas nilai-nilai yang tinggi, dan hendaknya kehidupan keluarga "condusive" yang membantu pembentukan kepribadiankepribadian yang kita inginkan sebagai otang tua.

\section{b. Prestasi belajar}

Kita menghendaki dan menuntut bahwa anak-anak kita belajar denan tekun, serta berprestasi sebaik mungkin. Kebiasaan belajar yang baik, disiplin diri harus sedini mungkin kita tanamkan karena kedua hal ini secara mutlak harus dimiliki anak-anak kita kebutuahan untuk berprestasi tinggi ('n-achievement) harus selekas mungkin kita tanamkan pada diri anak 
dengan jalan meng-expose mereka pada "standar of excellen" karena hanya dengan n-achievement yang tinggi kita kembangkan jiwa dan sikap "entrepreneur", kepribadian yang mau bekerja keras serta berani menghadapi kesulitan dan jika perlu kesalahan, demi keberhasilan proyek-proyek yang besar.

Yang dibutuhkan anak, dalam keadaan ini adalah pengertian dan waktu dari pihak kita serta pujian, bila anak menunjukkan usaha yang sungguh-sungguh ia tetap tidak berhasil. Pujian dalam keadaan anak seperti ini merupakan vitamin yang harus kita berikan tanpa takut "over dose". Janganlah kita menambah frustasi anak, ini hanya akan dan memberatkan persoalnnya.

\section{c. Kegemaran membaca}

Untuk membina kegemaran membaca, hendaknya kita sendiri menunjukkan kegemaran itu, misalnya: dengan membaca surat kabar setiap pagi, buku majalah yang bermutu kemudian mendiskusikannya.

\section{d. Makan bersama}

Makan bersam hendaknya dijadikan suatu peristiwa atau kebiasaan yang menyenangkan, yang ditunggu-tunggu oleh seluruh keluarga. Makan bersama ini hendaknya merupakan satu-satunya keesempatan yang dapat digunakan anak untuk dengan bebas dan secara spontan menceritakan pangalamanpangalamannya di sekolah, di jalanan dan dengan teman-temannya, orang tua hendaknya mau belajar mendengar segala curahan hati anaknya.

\section{e. Hoby}

Jika kita menghendaki bahwa anak-anak kita mempunyai hobi, hendaknya kita membantu meraka dalam melaksanakan hobi tersebut, sehingga hobi itu benar-benar berkembang. Hendaknya orang tua memberikan kebebasan kepada anak untuk berada bersama-sama dengan teman-teman. Jika hubungan orang tua dan anak bersifata terbuka, d nada banyak pengertian dan inteese pada pihak orang tua, tidak perlu para orang tua merasa terlalu khawatir akan terjadi hal-hal yang tidak diinginkan.

\section{f. Mereka bukan lagi anak-anak}

Orang tua hendaknya mengakui hal ini. Kepada remaja hendaknya sudah dapat diberikan kebebasan untuk, dalam hal-hal tertentu, mengambil keputusan atas tanggung jawab sendiri.

\section{g. Pendidikan seks}

Dalam periode ini anak-anak dan remaja kita sudah memerlukan pendidikan seks, pendidikan tersebut adalah pendidikan yang berhubungan dengan perubahan fisik dan biologis yang dialami dalam periode ini. Kita memberikan pengertian kepada mereka, bahwa mereka harus dapat menerima, memelihara dan menghormati keadaan tubuh mereka dan bahwa perubahan-perubahan ini akan menyebabkan adanaya "seximpulse", suatu "dorongan dari 
dalam" yang belum pernah mereka alami sebelumnya.

\section{h. Pendidikan agama}

Dalam pendidikan agama hendaknya diusahakan agar ajaranajaran agama tidak hanya diketahui tetapi juga agar benar-benar difahami dan dihayati sehingga dapat menimbulkan keinginan besar unruk hidup sesuai dengan kehendak Tuhan Yang Maha Esa.

\section{i. Sikap positif terhadap kerja}

Orang atua hendaknya menanamkan sikap positif terhadap pekerjaan rumah tanpa menggurui sehinnga anak dengan sendirinya melaksanakan pekerjaan rumah.

Akhirnya bila iklim dan suasan rumah kita hangat dan di dalamnya dapat dirasakan adanya perhatian, pengakuan, pengertian, penghargaan, kasih sayang, saling percaya dan waktu disediakan oleh orang tua bagi anak-anak. Maka mereka akan berusaha untuk hidup sesuai dengan nilai-nilai yang kita junjung tinggi.

\section{Harapan Terhadap Remaja}

Abu ahmadi dan Munawar Sholeh (1991:96-98) berpendapat bahwa, anak dan remaja adalah generasi junior (penerus), yakni mereka menjadi bakal atau calon yang akan menggantikan tugas-tugas para seniornya. Untuk itu harapan-harapan apa saja terhadap mereka?:

a) Memiliki nilai-nilai keimanan yang kuat, yakni, mereka mempunyai pedoman atau pegangan (prinsip hidup dan agama) sehingga mereka tidak terjerumus ke hal-hal yang dapat merugikan mereka (seks bebas dan narkotika).

b) Bertata karma yang baik dan berbudi luhur terhadap sesama (saling menghormati, suka menolong)

c) Belajar dengan giat dan tekun, agar segera dapat menyelesaikan studinya dan dapat ikut serta dalam pembangunan bangsa

d) Berprestasi, dengan ini orang lain dapat mengakui dan mmenghargai bakat serta kemampuan mereka.

e) Banyak membaca. Yakni, membaca literatur yang sehat dan bermutu, agar dapat memperluas horison dan cakrawala mereka dan tidak gagap terhadap ilmu pengetahuan dan teknologi sehingga mereka dapat bersaing di era globalisasi seperti ini

f) Mempunyai hoby dan kegiatan bermanfaat untuk mengisi waktu luang disamping kegiatan belajar (menjahit, melukis) dan juga dapat menjadikan usaha untuk meningkatkan ekonomi mereka.

g) Bertanggung jawab atas setiap seuatu yang mereka lakukan

h) Disiplin dalam setiap hal

i) Dapat membagi waktu dengan baik antara beribadah, belajar, bermain dan berkumpul bersama keluarga.

j)Dapat melaksanakan hak dan kewajiban mereka dengan seimbang. 
Jika remaja memiliki poin-poin daiatas, maka bangsa akan dapat berkembang dengan pesat serta dapat meningkatkan taraf hidup bangsa di kanca dunia

\section{Daftar Pustaka}

Ahmadi, Abu dan Munawar Sholeh, Psikologi Perkembangan, (Jakarta: Rineka Cipta, 1991)

M. P Knoers, F. J Monks dan Siti Rahayu Haditomo, Psikologi Perkembangan, (Yogyakarta: Gajah Mada University Press, 1982)

Syambu, Yusuf. Psikologi Perkembangan Anak dan Remaja, (Bandung: Remaja Rosdakarya, 2002) 